eCAM 2006;3(2)229-235

doi:10.1093/ecam/nel034

\title{
Review
}

\section{The State of the Art of Traditional Arab Herbal Medicine in the Eastern Region of the Mediterranean: A Review}

\author{
Hassan Azaizeh ${ }^{1}$, Bashar Saad ${ }^{1,2}$, Khalid Khalil ${ }^{1}$ and Omar Said ${ }^{1}$ \\ ${ }^{1}$ The Galilee Society R\&D Center (Affiliated with Haifa University, Haifa, Israel), PO Box 437, Shefa Amr 20200, Israel \\ and ${ }^{2}$ Faculty of Allied Medical Sciences, Arab American University, PO Box 240, Jenin, Palestine
}

\begin{abstract}
Historical and current studies indicate that the Eastern region of the Mediterranean has been distinguished from other regions by a rich inventory of complementary alternative medicine (CAM), in particular herbal medicine. Data collected from several surveys and studies indicate that there is a flourishing and well-developed trade of herbs. These surveys also reveal that 200-250 herbs are used in treating human diseases and are sold or traded in market places in the Mediterranean region or internationally. In addition, some of these herbs are rare or even endangered species. In regard to the status of the know-how of herbalists, unfortunately, herbal medicine in our region is mostly prescribed by ethnopharmacologists symptomatically — based on signs and symptoms alone, rather than as a result of a full understanding of the underlying disease. In some cases, herbs used today may not even correspond to the plants described originally in the old literature, as the former are cultivated from herbs that went through different breeding procedures throughout several centuries. This article presents a systematic review of both the state of the art of traditional Arab herbal medicine and the status of the know-how of Arab herbalists.
\end{abstract}

Keywords: Arab herbal medicine - bioactive ingredients - ethnopharmacology - medicinal herbs

\section{Historical Background}

For many centuries after the fall of the Roman Empire, the Arabic world was the center of scientific and medical knowledge. Texts from Greece and Rome were translated into Arabic and studied by Islamic scholars. They developed and refined Hippocrate's theories and Islamic physicians began to use the regulation of diet, exercise and the prescription of medicinal herbs in the treatment of their patients. Arabs in the Baghdad region were the first in history to separate medicine from pharmacological science. The differentiation and separation of two scientific disciplines, medicine and pharmacy, began during the eighth century. It is very important to note the fact that the first models of professional pharmacy were found among the Arab population. The first drug stores in

For reprints and all correspondence: Dr. Hassan Azazieh, R\&D center-GS, Industrial Zone, Shefa Amr 20200, Israel. Tel: +972-4-950-50-23/4;

Fax: +972-4-950-50-25/4; E-mail: hazaizeh@yahoo.com/hazaizi@ gal-soc.org the world were established in the Arab world (Baghdad, 754). The forms used in that period are still used in the therapy and some formulations of drugs can be found in pharmacopeas even today $(1,2)$. Experts in the pharmaceutical sciences undertook the extraction and preparation of remedies. Physicians were now responsible only for diagnosis of the diseases and follow-up with the treatments given. This marked a turning point in pharmaceutical science and helped it to develop into a complex field. Pharmacologists and ethnopharmacologists started to search for different ingredients and extracts to be used as remedies, and studied the chemical properties of materials used in disease management. For the first time, chemists such as Jaber Bin Hayan investigated methods to extract and purify different compounds such as alcohol, nitric acids, sulfuric acids and Royal acid which were used to dissolve gold $(3,4)$. Plant extracts were prepared and taken orally, applied externally, and administered by fumigation and vapor inhalation. The Egyptians were also credited with the early medicinal use of wine, castor oil, marijuana, opium, mints and beer made from barley and wheat (5).

(C) The Author (2006). Published by Oxford University Press. All rights reserved.

The online version of this article has been published under an open access model. Users are entitled to use, reproduce, disseminate, or display the open access version of this article for non-commercial purposes provided that: the original authorship is properly and fully attributed; the Journal and Oxford University Press are attributed as the original place of publication with the correct citation details given; if an article is subsequently reproduced or disseminated not in its entirety but only in part or as a derivative work this must be clearly indicated. For commercial re-use, please contact journals.permissions@ oxfordjournals.org 


\section{Herbal Medicine in Bilad el-Sham}

In this review we will focus on the development and current status of herbal medicine in the Middle Eastern region and in particular on a region covering significant parts of the present-day Syria, Palestine, Lebanon, Israel and Jordan, used to be called Bilad el-Sham by the Arab rulers and scholars of that time $(1,2)$. Recent studies investigated the medical uses of natural substances in medieval and Ottoman al-Sham (the Levant) and revealed that there were 286 medicinal substances in use as traditional compounds (6-8). These studies involved meticulous surveying of a wide range of historical sources spanning $\sim 1100$ years, which include traditional literature, travelogues, archives, the Genizah, Ottoman Levant and other sources. The region under study served as the geographic origin of the majority of medical substances, only a minority of the materials was imported. In fact, the al-Sham region was an independent source of production and marketing of medicinal substances during the medieval and Ottoman period.

Medicinal plants contain curative bioactive ingredients which have proven to be valuable as primary or supplemental therapies when carefully applied (9). Until last century most medicines were derived directly from plants or animals. Despite the increasing use of synthetic drugs, natural pharmaceuticals have persisted as the 'treatment of choice' for different diseases in societies throughout the world. Many local remedies used throughout the Middle East region have never been properly explored, researched, evaluated or exploited, compared to, for example, Chinese medicine, which is further away from Europe in theory (10), culture and practice. Medicinal herbs are great resources for various pharmaceutical compounds and urgent measures are required to protect these plant species from their natural destruction and disappearance. Indeed, there is a real danger of indigenous Arab medicinal practices and knowledge disappearing altogether, further weakening traditional Arab culture and creating more insecurity, as well as forsaking a resource of inestimable economic and health care importance.

\section{The Uses of Medicinal Herbs and Extracting their Active Ingredients}

Herbal remedies and alternative medicines are used throughout the world, and in the past herbs were the only original source of most drugs. Over 20000 medicinal herbs were recently inventoried in by the World Health Organization (WHO), and $\sim 250$ species had been analyzed to identify their bioactive chemical components (11). The hills and mountains of the Middle Eastern region (mainly historical Palestine) are covered with $>2600$ plant species of which $>700$ are noted for their uses as medicinal herbs or as botanical pesticides $(12,13)$. Ethnopharmacological research may represent a crucial step in the development of drugs from natural sources (14). A long history of trial and error has led to the correlation of a particular herb with the amelioration and/or complete curing of certain disease.

\section{Criteria Used to Identify a Potential Medicinal Plant}

The physical characteristics of the herb, including size, shape, color, texture and taste have traditionally served as important criteria in their selection for therapeutic purposes. Seeds with kidney shape are used for treating kidney stones: e.g. Alhagi maurorum (Medik.) and Astragalus macrocarpus (DC.). Roots' shape similar to human body or fruits that resemble human testis are used traditionally for stimulating sexual desire or treating sexual weakness: Mandragora autumnalis (Bertol.) and A. macrocarpus (DC.). The doctrine of signatures is reflected in some of the uses of certain herbs: e.g. the yellow decoction obtained from leaves of Rhamnus alaternus (L.) and the yellow juice from the fruits of Ecbalium elaterium (L.) are used for treating jaundice and liver diseases $(15,16)$. For several herbs, the plant's common name in Arabic refers to its use. This is the case for Glaucium oxylobum (L.), Hypericum lanuginosum, Marcurialis annua (L.) and Ceterrach officinarum (Willd.). All four plants are called 'The wounds' herbs', since they are used for treating external wounds. The exchange of people and culture between the Middle East, Europe and the Far East has brought with it exchange of information, so that a given herb is used similarly in all these areas: e.g. Ammi visnaga (Lam.) for kidney stones; Matricaria aurea (L.) for stomach aches; Malva nicaensis (All.) for wounds $(15,16)$.

\section{Preparation Techniques}

Several techniques are used by traditional herbalists to obtain the beneficial phytochemical components from the selected species. The majority of botanically based remedies are consumed orally in the form of tea or other drink containing either diluted or concentrated chemical ingredients $(12,13,15,17,18)$. The tea is generally produced from the various parts of the herbs through infusion or as decoctions (15). Heating a raw plant in a fluid medium not only aids the extraction and concentration of curative substances, it also acts to eliminate poisons and impurities prior to consumption $(19,20)$. Since there is no sharp dividing line separating food and drugs, it is not surprising that various edible plant parts have been used as sources of both nutrition and medicine in different cultures $(9,15)$. The seeds of Nigella sativa (L.), as an example, could be considered as either a meal for food consumption or as a preventive of high blood pressure and heart diseases (15). The oil as well as the fruits of Olea europaea (L.) is important food nutrition and an antioxidant or diabetes preventive in many societies. Some plant species are used for treating several types of pathological conditions: e.g. Teucrium polium (L.) is a perennial shrub commonly used in folk medicine as anti-diabetic, anti-inflammatory, anti-ulcer, hypotensive and liver diseases $(15,21)$. Phytochemical investigations have shown that this herb contains various compounds such as flavonoids, iridoids and crisiol (22). T. polium (L.) crude extract significantly decreased $(64 \%)$ the blood glucose concentration in treated animals and enhanced insulin secretion (135\%) after a single dose of plant extract (23). Table 1 lists a number of plant species 
Table 1. Medicinal herbs used to treat diabetes in the Eastern Mediterranean region*

\begin{tabular}{|c|c|c|}
\hline Plant species & Preparation & Additional uses \\
\hline Astragalus macrocarpus DC. & Leaf decoction & Heart diseases \\
\hline Ceratonia siliqua $\mathrm{L}$. & Leaf decoction & Herpes and lip sores \\
\hline Cichorium pumilum Jacq. & Foliage decoction & Bacterial infection, poisoning and rheumatism \\
\hline Cupressus sempervirens L. & Fruit decoction & Antiseptic and nervous system \\
\hline Eryngium creticum Lam. & Foliage decoction & Liver diseases, poisoning, anemia and infertility problems \\
\hline Juglans regia $\mathrm{L}$. & Leaf and flower decoction & Asthma and sexual weakness \\
\hline Lupinus varius Gaertn & Soaked seeds & Kidney stones \\
\hline Mercurialis аппиа $\mathrm{L}$. & Leaf decoction & Cancer and skin diseases \\
\hline Morus nigra $\mathrm{L}$. & Leaf, stem and fruit decoction & Teeth and gum inflammation and cholesterol \\
\hline Paronychia argentea Lam. & Leaf and flower decoction & Stones in kidney and heart diseases \\
\hline Pinus halepensis Mill. & Leaf and seed decoction & Sexual weakness \\
\hline Prosopis farcta Sol. Ex Russell & Foliage decoction & Menstrual cramps and kidney stones \\
\hline Quercus calliprinos Decne & Fruit and bark decoction & Cancer, bed wetting and ulcer \\
\hline Salvia fruticosa Mill. & Foliage infusion & Stomach ache, intestinal gas and inflammation \\
\hline Sarcopoterium spinosum $\mathrm{L}$. & Leaf, seed and root decoction & Intestine pain, kidney diseases and ulcer \\
\hline Smilax aspera $\mathrm{L}$. & Fruit and root decoction & Poisoning \\
\hline Teucrium polium $\mathrm{L}$. & Foliage decoction & Kidney stones, liver diseases, stomach and intestine inflammation \\
\hline Trigonella foenum-graecum $\mathrm{L}$. & Seed decoction & Sexual weakness, stomach and intestinal pain \\
\hline
\end{tabular}

*Data from Said et al. (15) and Dafni et al. (16).

that have been used traditionally to treat diabetes in Arab communities.

Other methods include the inhalation of aerosols (e.g. Pimpinella anisum L.), essential oils (e.g. Jasminus fruticans L.) and vaporized plant juices or teas, as well as absorption to the skin (e.g. Portulaca oleracea L.) $(12,13,15,18)$. In making a poultice, for example, plant parts are ground or crushed and combined with hot water or other liquids to create a medicinal paste or plaster. The resulting mixture is placed directly on wounds, bruises, aritric joints, burns, insect and animal bites, rashes, swellings, wrinkles or dermatological irritations (e.g. C. officinarum Willd., Citrullus colocynthis L., Eryngium creticum Lam.) (12,13,15,18). Table 2 summarizes a partial list of plants prescribed by ethnopharmacologists for treating skin disorders.

\section{Herbal-derived Active Compounds}

Plants have an almost limitless ability to synthesize aromatic substances that have been evaluated for their therapeutic potential. These include alkaloids, coumarins, saponins and flavonoids $(24,25)$. Flavonoids are probably the best known of these substances due to their antioxidant properties (26). The therapeutic benefit of several plant species used by traditional herbalists, at least in part, was attributed to their effective inhibition of oxidative processes (27-29). Several of these herbs are used traditionally in treating liver diseases, where Pistacia lentiscus (L.) was found effective in suppressing iron-induced lipid peroxidation in rat homogenates as Trolox, the water soluble analog of vitamin E, and did not adversely affect cell membrane integrity or suppress mitochondrial respiration in cultured HepG2 and PC12 cells (29). A single dose of the aqueous boiled and non-boiled decoctions prepared from the leaves of $P$. lentiscus (L.) blunted the effects of single intoxicating dose of the known hepatotoxin, carbon tetrachloride (30). Silybum marianum (L.) (milk thistle) is currently the most well researched plant used traditionally by Arab herbalists in the treatment of liver diseases (15). The active constituents of milk thistle are flavonolignans including silybin, silydianin and silychristine, collectively known as silymarin (31,32). Silymarin is not water soluble and so cannot be taken as a tea but as an encapsulated standardized extract.

\section{The State of the Art of Traditional Arab Herbal Medicine}

The Eastern region of the Mediterranean has been distinguished throughout generations with a rich inventory of natural medicinal herbs used by local herbalists (1$4,7,8,12,13,15,33-36)$. In contrast to the historical importance of Arab medicine, current research into the different modalities of complementary alternative medicine (CAM) in our region and the know-how of modern Arab herbalists are limited. The number and species of medicinal plants that are currently used by herbalists and practitioners were described in a comprehensive survey that was conducted on practitioners and herbalists using medicinal plants in an area that included Israel, the West Bank and the Golan Heights (15,37). Results obtained in this extensive survey indicate that (i) $\sim 129$ plant species are still in use in the treatment of various human diseases including liver, skin, respiratory, digestive, cancer and other diseases; (ii) the number of species of plants being 
Table 2. Medicinal herbs used to treat skin diseases in the Eastern Mediterranean region*

\begin{tabular}{lll}
\hline Plant species & Preparation & Additional uses \\
\hline Alcea setosa Boiss. & Leaf, flower and root decoction & Stomach and intestine pain, inflammation and asthma \\
Ammi visnaga L. & Flower and seed decoction & Kidney inflammation and respiratory system (asthma) \\
Asphodelus microcarpus Salzm. and Viv. & Bulb and root juice & Ectoderm parasites and jaundice \\
Cyclamen persicum Mill. & Leaf and bulb decoction & Ear infections \\
Eruca sativa Miller & Seed oil & Sexual weakness and hair loss \\
Ficus sycomorus L. & Stem milky sap & Coughing, digestive system and anemia \\
Glaucium corniculatum L. & Poultice of macerated roots & Cholesterol and acne \\
Inula viscosa L. Ait. Inula & Foliage macerated in oil & Muscle relaxation and infertility \\
Lavandula officinalis Chaix and Kitt & Leaf, flower and seed infusion & Urinary system, asthma and nerve system \\
Lycium europaeum L. & Root decoction & High blood pressure and diabetes \\
Malva nicaensis All. & Whole plant decoction & Coughing and wounds \\
Myrtus communis L. & Leaf infusion & Stomach, intestine pain and inflammation \\
Paronychia harmala L. & Seed infusion in olive oil & Wounds and lice \\
Sanguisorba minor Scop. & Whole plant decoction & Ulcer, burns and wounds \\
Saponaria mesogitana Boiss. & Root decoction & Liver diseases, stones in kidney and joint inflammation \\
Scolymus maculatus L. & Stem decoction & Intestine and kidney inflammation \\
Solanum nigrum L. & Foliage decoction & Wounds and sun burn \\
Thymelaea hirsuta L. Endl. & Foliage paste & Coughing and respiratory system \\
Viola odorata L. & Foliage decoction & Respiratory system, stomach and intestine inflammation \\
Tamarix aphylla L. H. Karst. & Leaf decoction & Eye inflammation and fever \\
\hline
\end{tabular}

*Data from Said et al. (15) and Dafni et al. (16).

used by practitioners was nearly twice as many as previously thought; and (iii) some plants were discovered as having medicinal properties for the first time (15). Similar conclusions were drawn from another recently published ethnopharmacological survey conducted in Jordan where $>100$ herbalists interviewed in this survey revealed that there are $\sim 150$ plant herbs still in use as traditional source of natural substances (18). Currently, $<200-250$ plant species are still in use in Arab traditional medicine for the treatment of various diseases $(7,8,15)$. The number of herbal-derived substances that are in use as traditional compounds is $\sim 286$ (8).

Research into the traditional medicinal herbs has also been conducted in many Arab countries such as Syria, Morocco, Yemen, Egypt and others (38-41). The most recent survey conducted on the potential uses of plant species of the coastal Mediterranean region in Egypt (41) recorded 230 species belonging to eight families. Only $89 \%$ of these species have medicinal values and are used for treating diseases. Among these species, $62 \%$ are common species, $12.7 \%$ are occasional, while $13 \%$ are rare. According to these authors, all rare species, most of the occasional species and even some of the common ones are going to disappear as a result of overuse. Our heritage of plant herbs that flourished a few centuries ago is now in rapid decline. A report by the Arab Union for Agriculture and Development (2000) has indicated that out of 814 plant species used in traditional Arab medicine only 23 herbs are still in use in pharmaceutical industry, 55 are used in perfume and cosmetics, 34 are involved in food industry and 10 species are used as botanical pesticides. The
Middle Eastern region was covered with $>2600$ plant species of which $>700$ were noted for their use as medicinal herbs or as botanical pesticides. Unfortunately, recent ethnopharmacological surveys revealed that $<200-250$ plant species are still in use in Arab traditional medicine for the treatment of various diseases $(15,17,18,42)$. Moreover, many plant herbs used in traditional medicine are now rare or endangered species. Table 3 lists some of the important rare and endangered plant species used traditionally for treating human diseases or as botanical pesticides. There are several factors endangering plant diversity or even causing eradication of these herbs which include habitat loss, habitat degradation and overharvesting (43).

\section{The Status of the Know-How of Arab Herbalists of the Region}

In the middle ages, in the periods of Muslim and Christian rule in the Near East, herbalists and owners of stands for preparing and selling medicines were recognized as a body under professional supervision by the authorities (44). In contrast, recent surveys $(18,37)$ have revealed that most of the practitioners do not have any formal education in the field of medicine and pharmacy. They are also wary of joining local unions or cooperating with local physicians for fear of losing their professional niche. The competition amongst healers is quite high, perhaps because of the general insecurity surrounding this fringe activity. The same phenomenon is noticed in many Caribbean societies, where traditional healers 
Table 3. Selected list of important rare and endangered plant species used traditionally for treating human diseases or as botanical pesticides

\begin{tabular}{llc}
\hline Plant species* & Applications & Red plant number** \\
\hline Anchus negevensis & Anti-parasites, skin wounds and anti-coagulation & 12 \\
Anchus ovata & Anti-parasites, skin wounds and anti-coagulation & 6 \\
Eryngium barrelieri & Liver diseases and anti-toxins & 7 \\
Eryngium maritimum & Liver diseases and anti-toxins & 6 \\
Euphorbia dendroides & Botanical pesticides & 9 \\
Euphorbia hirsuta & Anti-parasite & 7 \\
Ophioglossum lusitanicum & Anti-parasite, skin wounds and anti-coagulation & 8 \\
Ophioglossum polyphyllum & Anti-parasite, skin wounds and anti-coagulation & 6 \\
Teucrium procerum & Diabetics, liver diseases and wounds & 12 \\
Teucrium scordium & Chronic skin disease, dyspepsia and hemorrhoids & 7 \\
Ziziphus nummularia & Diarrhea, lung inflammation and anti-congestion & 8 \\
\hline
\end{tabular}

*Rotem (Israel Plants information center), University botanical garden Jerusalem, 2005 online, http://www.botanic.co.il/english/research/rare.htm, cited April 20, 2006.

**The Red number is an additive index, summarizing values of four parameters: rarity, declining rate and habitat vulnerability, risk through attractivity and distribution type. The higher the number is the more the plant is at risk.

acquire their positions through inheritance ('transmission'). It is believed that these skills and abilities are passed down through family lines and visions, rather than also by training and apprenticeship (45). A recent survey (37) reported that only 31 professional Arab practitioners in Israel, Palestine and the Golan Heights are still practicing. The total number of practitioners interviewed was $>60$, but many of them were excluded from the survey because their know-how was very limited. This number is significantly less in comparison with that in previous surveys $(12,16)$.

Each interviewed practitioner has his own methods of preparation, following the tradition of his parents or teachers. The process of transmitting knowledge from one generation to the next is complex one, and the end result is not always identical. A recent ethnopharmacological survey conducted in Jordan, where $>100$ herbalists were interviewed, found that most of the herbalists were not educated or trained in the field of herbal medicine beyond the knowledge passed down from their predecessors (18). It was also found that the traditional herbalists were not licensed for this particular purpose. This survey concluded that there is a necessity for proper handling and licensing of herbal medicines. A similar conclusion was also drawn by a comparable survey conducted by our group (37). The scope of experience of those surveyed practitioners varied greatly, depending upon their location, i.e. in the Golan Heights, there is only one practitioner who works part-time, in comparison to the West Bank and Galilee region, in which more practitioners were found to depend on their practice as a sole source of income (37). This indicates that this practice may disappear in some regions of the Middle East. The status of the Arab herbalists according to our recent survey is summarized below:

- Most practitioners have very limited knowledge in the identification of species and procedures for preparing medicinal remedies. They buy readymade or partially prepared remedies from 'Attarah' shops, where plant materials are sold, and do not collect plants from natural sources.

- Younger practitioners were even less experienced than their older counterparts, indicating that traditional knowledge is being partially lost with new generations.

- Many practitioners are turning to 'mystical' or 'magical' methods of healing, indicating a loss of the rich knowledge of practical plant medicine.

- The level of education of practitioners is in decline, where many practitioners often rely on shepherds for knowledge, identification and collection of plant materials for their practice.

- Plant mixtures are of poorer quality and less variety in comparison to the past. Moreover, plants used in certain regions are not used in others. For example, local practitioners from the Negev region of Israel use only plant species found in the desert.

- A very limited exchange of information takes place between the healers in the same area. The occupation of traditional healer is a family matter and passed on by inheritance; therefore, when the present generation of healers dies, the know-how may die with it because children of the practitioners have no interest in the subject.

\section{The Need for Regulations}

These surveys also conclude that there is a necessity for proper handling and licensing of herbal medicines. The increasing popularity of over-the-counter health food, nutraceuticals and medicinal products from herbs or other natural sources in developed countries (46) indicates that the public is not satisfied with 'orthodox' allopathic medical treatment. However, over the past decade several episodes in developed 
communities indicated adverse effects, sometimes lifethreatening, allegedly arising consequential to taking of herbal products or traditional medicines from various ethnic groups $(46,47)$. In some cases, adulteration, inappropriate formulation, or lack of understanding of plant and drug interactions or uses led to adverse reactions $(18,48,49)$. In view of the progress of Western medicine, not only new synthetic drugs but also herbal remedies have to fulfill international requirements on quality, safety and efficacy $(47,50)$.

Recent ethnopharmacological surveys conducted by different groups in the Middle East support the necessity of proper handling of herbal medicine which requires suitable regulation and licensing in order to ensure supply of suitable and safe products $(18,42,51)$. Fortunately, today there is a countertrend underway to preserve natural botanical resources through and increasing emphasis on conservation by way of botanical gardens, greenhouses, herbariums, tissue cultures, propagation and seed banks $(52,53)$. The WHO regulations $(54,55)$ can be considered as a good basis for such regulations. In addition a uniform database should be established on the characteristics of these herbs, the methods used for the preparation of these remedies, their application as well as efficacy and toxicity tests in order to avoid negative impacts on the patients.

\section{Concluding Remarks}

Medicinal plants in the Middle Eastern region and worldwide are becoming increasingly rare due to the ongoing destruction of their natural habitat, overharvesting of wild species, and detrimental climatic and environmental changes. As a result, it is predicted that in semi-arid regions such as the Middle East, a number of species will disappear within the next 10 years, particularly in desert or dry areas where almost a third of native plants are found. This gives an added sense of urgency to the task of recording their identity and uses, and initiating programs of preservation of the genetic resource of medicinal plants of the region. This is paradoxical at a time when there is an increasing interest worldwide in herbal medicines accompanied by increased laboratory investigation into the pharmacological properties of the bioactive ingredients used to treat various diseases.

The picture today within the region is a general availability of modern medicine, widespread non-professional use of folk and natural remedies, and a small and declining professional tradition of Arab medicine. Recent surveys have found that ethnopharmocologists in the Middle East are increasingly distanced from the knowledge of their predecessors. This is largely because such knowledge is not written, and also because ethnopharmocologists do not directly collect the herbs from nature. These surveys also reveal a lack of information exchange amongst practitioners, and between practitioner and researcher. Additional research emphasis in the field of medicinal plants is required in the future on issues of safety, toxicity, proper dosages, contamination and potential interactions with synthetic and other natural drugs. In order to further reduce the possibility of human poisoning, new methods might also be introduced to detoxify phytotoxins. In order to revive this cultural heritage, botanical gardens and education centers in the Middle East should exchange knowledge and develop a regulatory framework on a regional scale.

\section{Acknowledgments}

The authors would like to thank Ms Arisha Ashraf from the Galilee Society, Shefa-Amr, Israel, for her constructive comments and to Ms Susanne Grund from the Galilee Society for her great help in combining the list of the rare and endangered plant species.

\section{References}

1. Bacher W. Scham als Name Palastinas. The Jewish Quarterly Review 1906;18:564-5.

2. Saad B, Azaizeh H, Said O. Tradition and perspectives of Arab herbal medicine: a review. Evid Based Complement Alternat Med 2005;2:475-9.

3. Bin Murad I. Research into the History of the Medicine and Pharmacology of the Arabs. Beirut, Lebanon: Dar AlGarb AlIslami, 1991 (in Arabic).

4. AlTurkimany JOA. AlMoatamad Fi Aladweah Almofradah (The source of the single Pharmaceuticals). Revised by AlSaka M. Beirut, Lebanon: Dar AlKalam Publishing, 1993 (in Arabic).

5. Shafik A, Elseesy W. Medicine in ancient Egypt. In: Seli H, Shapiro H (eds). Medicine Across Cultures. Boston: Kluwer, 2003, 27-48.

6. Lev E. Reconstructed materia medica of the Medieval and Ottoman al-Sham. J Ethnopharmacol 2002;80:167-79.

7. Lev E, Amar Z. Ethnopharmacological survey of traditional drugs sold in Israel at the end of the 20th century. J Ethnopharmacol 2000;72:191-205.

8. Lev E, Amar Z. Ethnopharmacological survey of traditional drugs sold in the Kingdom of Jordan. J Ethnopharmacol 2002;82:131-45.

9. Halberstein RA. Medicinal plants: historical and cross-cultural usage patterns. Ann Epidemiol 2005;15:686-99.

10. Bhushan P, Dnyaneshwar W, Pushpangadan P, Narendra Bhatt. Ayurveda and traditional Chinese medicine: a comparative overview. Evid Based Complement Alternat Med 2005;2:465-73.

11. Narango P. Urgent need for the study of medicinal plants. In: Schultes R, Von Reis S (eds). Ethnobotany: Evolution of a Discipline. Portland. Oregon: Dioscorides Press, 1995; 362-8.

12. Ali-Shtayeh MS, Yaniv Z, Mahajna J. Ethnobotanical survey in the Palestinain area: a classification of the healing potential of medicinal plants. J Ethnopharmacol 2000;73:221-32.

13. Palevitch D, Yaniv Z. Medicinal Plants of the Holy Land. Tel Aviv, Israel: Modan Publishing House, 2000.

14. Cooper EL. Drug discovery, CAM and natural products. Evid Based Complement Alternat Med 2004;1:215-7.

15. Said O, Khalil K, Fulder S, Azaizeh H. Ethnopharmacological survey of medicinal herbs in Israel, the Golan Heights and the West Bank region. J Ethnopharmacol 2002;83:251-65.

16. Dafni A, Yaniv Z, Palevitch D. Etnobotanical survey of medicinal plants in Northern Israel. J Ethnopharmacol 1984;10:295-310.

17. Abu-Irmaileh BE, Afifi FU. Treatment with medicinal plants in Jordan. Dirasat 2000;27:53-74 (in Arabic with English abstract).

18. Abu-Irmaileh BE, Afifi FU. Herbal medicine in Jordan with special emphasis on commonly used herbs. J Ethnopharmacol 2003;89:193-7.

19. Halberstein RA, Davis JE. Biosocial aspects of high blood pressure in the Bahamas. Hum Biol 1984;56:317-28.

20. Johns T, Kubo I. A survey of traditional methods employed for the detoxification of plant foods. J Ethnobiol 1988;8:81-129.

21. Khleifat K, Shalkhanbeh J, Tarawneh K. The chronic effects of Teucrium polium on some blood parameters and histopathology of liver and kidney in the rat. Turk J Biol 2002;26:65-71.

22. Rizk AM, Hammouda FM, Rimpler H, Kamel A. Iridoids and flavonoids of Teucrium polium herb. Planta Med 1986;2:87-8.

23. Esmaeli MA, Yazdanparast R. Hypoglycaemic effect of Teucrium polium: studies with rat pancreatic islets. J Ethnopharmacol 2004;95:27-30. 
24. Watson AA, Fleet GWJ, Asano N, Molyneux RJ, Nash RJ. Polyhydroxylated alkaloids - natural occurrence and therapeutic applications. Phytochemistry 2001;56:265-95.

25. Barnes J, Anderson LA, Phillipson JD. Herbal Medicines. London, UK: Pharmaceutical Society, 2002.

26. Havsteen BH. The biochemistry and medical significance of the flavonoids. Pharmacol Ther 2002;96:67-202.

27. Azaizeh H, Ljubuncic P, Portnaya I, Said O, Cogan U, Bomzon A. Fertilization-induced changes in growth parameters and antioxidant activity of medicinal plants used in traditional Arab medicine. Evid Based Complement Alternat Med 2005;2:549-56.

28. Ljubuncic P, Portnaya I, Cogan U, Azaizeh H, Bomzon A. Antioxidant activity of Crataegus aronia aqueous extract used in traditional Arab medicine in Israel. $J$ Ethnopharmacol 2005;101:153-61.

29. Ljubuncic P, Azaizeh H, Portnaya I, Cogan U, Said O, Abu Saleh K, et al. Antioxidant activity and cytotoxicity of eight plants used in traditional Arab medicine in Israel. J Ethnopharmacol 2005;99:43-7.

30. Jankat S, Al Merie H. Evaluation of hepatoprotective effect of Pistacia lentiscus, Phillyrea latifolia and Nicotiana glauca. J Ethnopharmacol 2002;83:135-8.

31. Buzzelli G, Moscarella S, Giusti A. A pilot study on the liver protective effect of silybin-phosphatidylcholine complex (1dB1016) in chronic active hepatitis. Int J Clin Pharmacol Ther Toxicol 1993;31:456-60.

32. Morazzoni P, Montalbetti A, Malandrino S. Comparative pharmacokinetics of silipide and silymarin in rats. Eur J Drug Metab Pharmacokinet 1993;18:289-97.

33. Munke L. AlTadawy Be Alashab Fi Masr Alkademeh (Healing with Herbs in Old Egypt). Cairo, Egypt: Maktabat Madbouly, 1993 (in Arabic).

34. Palevitch D, Yaniv Z, Dafni A, Fridman Y. Survey of Wild Plants in Israel as a Pharmacological Source. Jerusalem: Ministry of Science, 1985 (in Hebrew).

35. AlAntaki DO. Attathkra, or Tathkarat Uli al Albab wa Aljame lil Ajab al Ojaab (The Reminder, or the Reminder to Wise People and the Miraculous Collector). Cairo, Egypt: Blak, 1877 (in Arabic).

36. Shams Aldeen A. Altadawy Fi Alashaab Kademan wa Hadethan (Healing with Herbs in the past and present). Beirut, Lebanon: Dar AlKutum Alelmeah, 1991 (in Arabic).

37. Azaizeh H, Fulder S, Khalil K, Said O. Ethnobotanical survey of local practitioners of the Middle Eastern region: the status of traditional Arabic medicine. Fitoterapia 2003;74:98-108

38. Ahmed MS, Honda G, Miki W. Herb Drugs and Herbalists in the Middle East. Tokyo, Japan: Studia culturae Islamicae, Institute for the Study of Languages and Cultures in Asia, 1979.

39. Honda G, Miki W, Saito M. Herb Drugs and Herbalists in Syria and North Yemen. Tokyo, Japan: Studia culturae Islamicae, Institute for the Study of Languages and Cultures in Asia, 1990.
40. Eddouks M, Maghrani M, Lemhadri A, Ouahidi ML, Jouad H. Ethnopharmacological survey of medicinal plants used for the treatment of diabetes mellitus, hypertension and cardiac diseases in the south-east region of Morocco (Tafilalet). J Ethnopharmacol 2002;82:97-103.

41. Heneidy SZ, Bidak LM. Potential uses of plant species of the coastal Mediterranean region, Egypt. Pak J Biol Sci 2004;7:1010-23.

42. Saad B, Dakwar S, Said O, Abu-Hijleh G, Al Battah F, Kmeel A, et al. Evaluation of medicinal plants hepatotoxicity in co-cultures of hepatocytes and monocytes. Evid Based Complement Alternat Med 2006;3:93-8.

43. Hamilton AC. Threats to plants: an analysis of Centers of Plant Diversity. In: Touchell DH, Dixon KW (eds). Conservation into the 21st Century. Volume Proceedings of 4th International Botanic Gardens Conservation Congress, Kings Park and Botanic Garden, Perth, Australia, 1997, 309-22.

44. Ibn Abi Usaybia. Uyun al-Anba fi Tabaquat al Atibba (The Resources of the News in the Layers of the Attributes). Dar El Kalam. Beirut, Lebanon 1965 (in Arabic).

45. Halberstein RA. Traditional botanical remedies on a small Caribbean island: Middle (Grand) Caicos, West Indies. J Altern Complement Med 1997:3:227-39.

46. Chan K. Some aspects of toxic contaminants in herbal remedies. A review. Chemosphere 2003;52:1361-71.

47. Elvin-Lewis M. Should we be concerned about herbal remedies? J Ethnopharmacol 2001;75:141-64.

48. Ernst E. Harmless herbs? A review of the recent literature. Am J Med 1998;104:170-8.

49. Ernst E. Herbal medications for common ailments in the elderly. Drugs Aging 1999;15:423-8.

50. Rousseaux C.G, Schachter H. Regulatory issues concerning the safety, efficacy and quality of herbal remedies. Birth Defects Res B Dev Reprod Toxicol 2003;68:505-10.

51. Pioroni A, Quave CL, Santoro RF. Folk pharmaceutical knowledge in the territory of the Dolomiti Lucane, inland southern Italy. J Ethnopharmacol 2004;95:373-84.

52. Summer J. The Natural History of Medicinal Plants. Portland, Oregon: Timber Press, 2000.

53. Chaudhuri AB, Sarkar DD. Biodiversity Endangered: India's Threatened Wildlife and Medicinal Plants. Jodhpur: Scientific Publishers, 2002.

54. Arkerele O. Nature's medicinal bounty: don't throw it away. World Health Forum 1993;14:390-5.

55. WHO, IUCN, WWF. Guidelines on the Conservation of Medicinal Plants. Published by The International Union for Conservation of Nature and Natural Resources (IUCN), Gland, Switzerland, in partnership with The World Health Organization (WHO), Geneva, Switzerland, and WWFWorld Wide Fund for Nature, Gland, Switzerland, 1993.

Received January 26, 2006; accepted May 12, 2006 


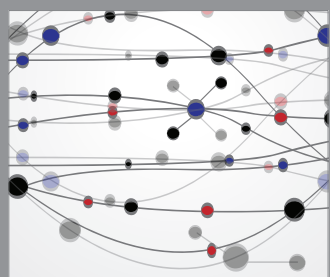

The Scientific World Journal
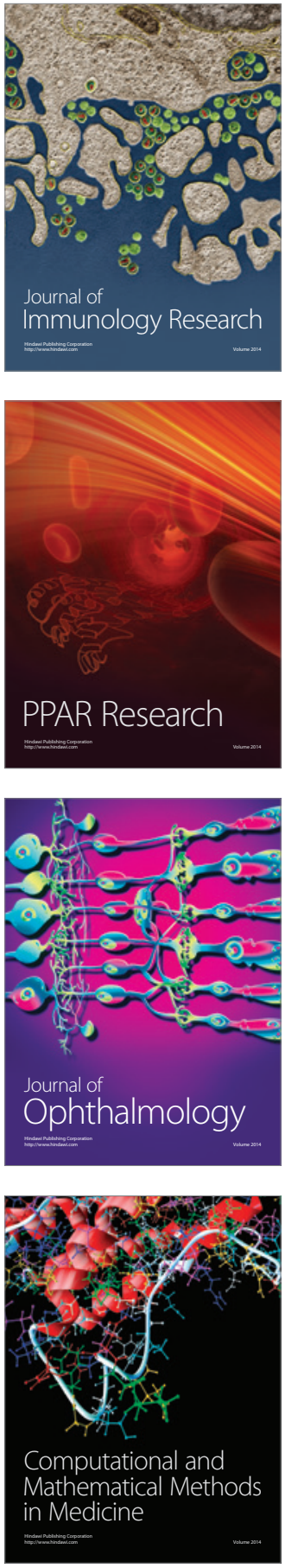

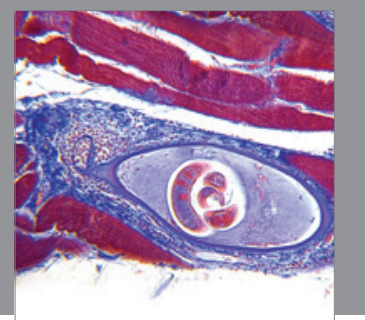

Gastroenterology

Research and Practice
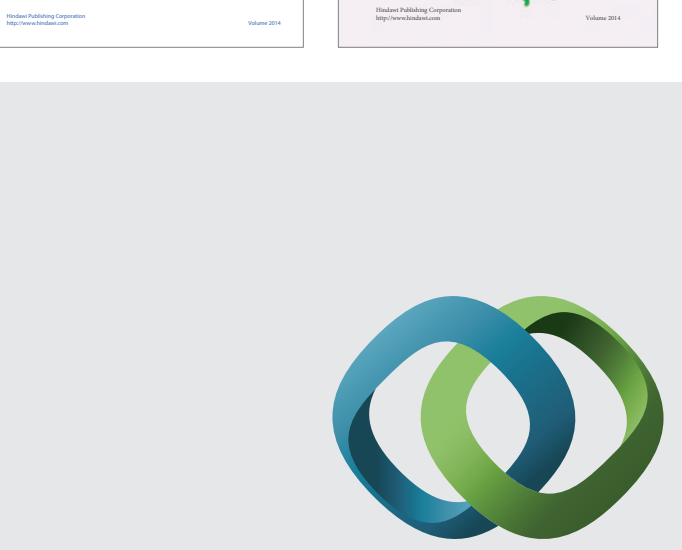

\section{Hindawi}

Submit your manuscripts at

http://www.hindawi.com
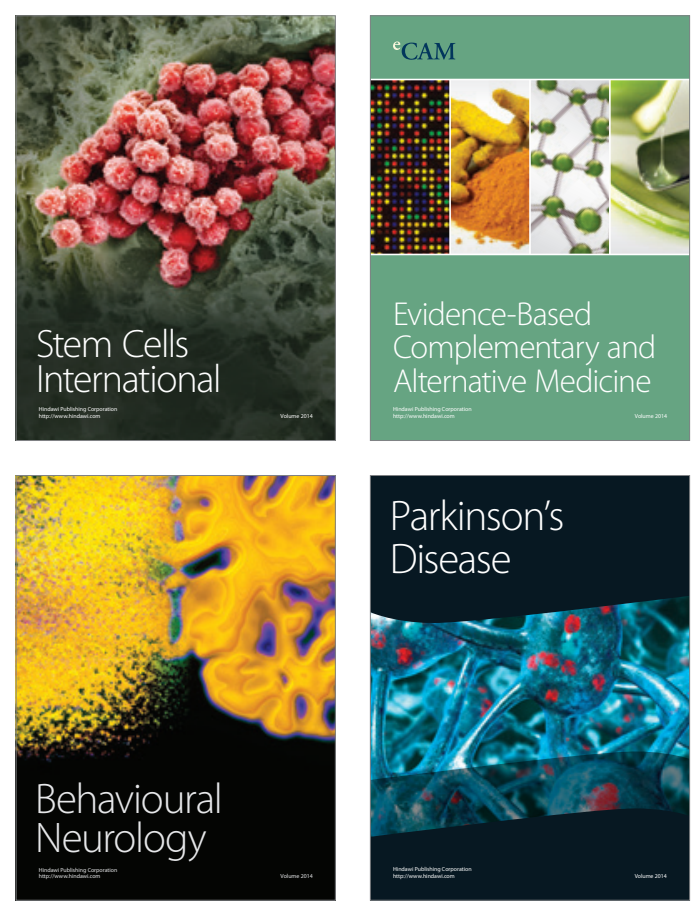

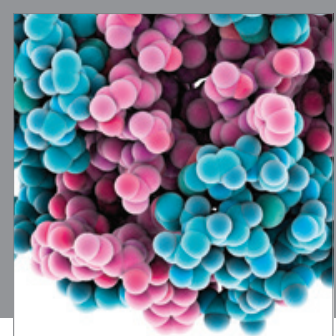

Journal of
Diabetes Research

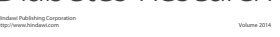

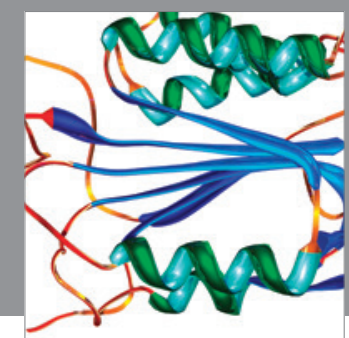

Disease Markers
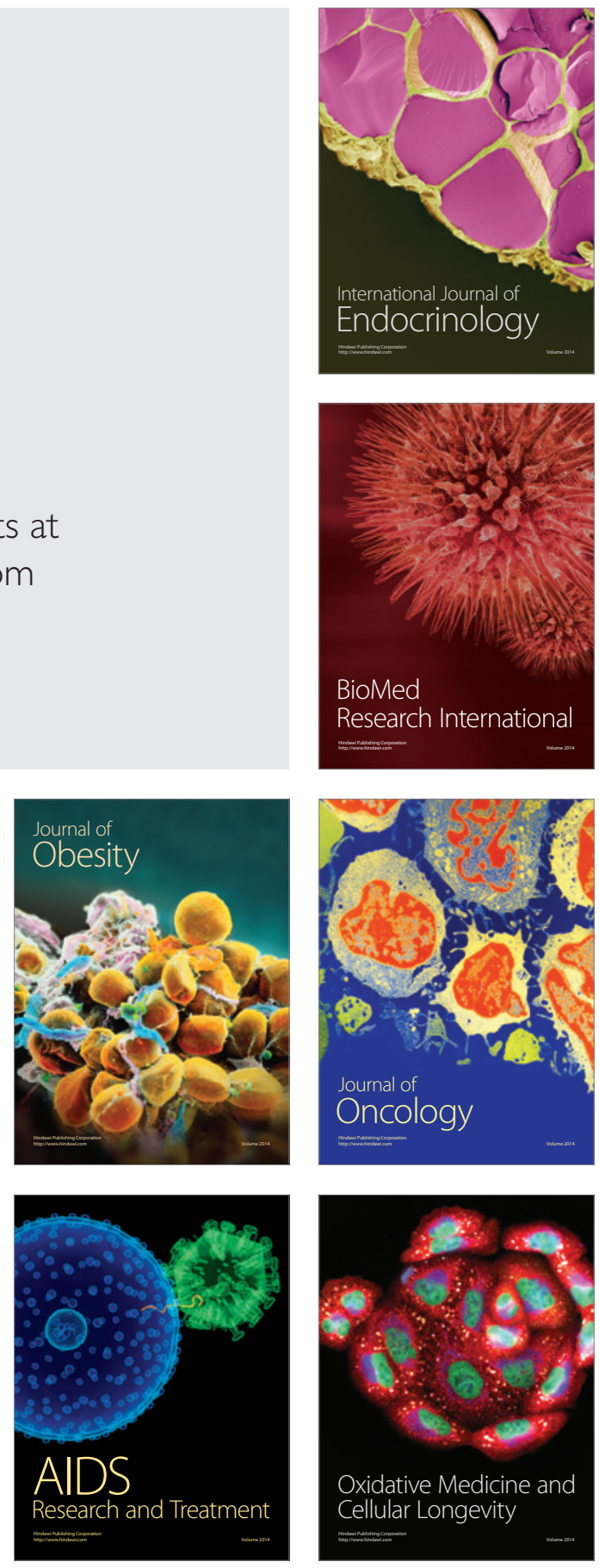